\title{
Survival of Acidovorax citrulli in infected melon tissues and in different edafoclimatic conditions
}

\author{
Aldenir de Oliveira Alves ${ }^{1}$, André da Silva Xavier ${ }^{2}$, Claudeana Souza da Conceição \\ Rosa de Lima Ramos Mariano ${ }^{4}$, Elineide Barbosa de Souza ${ }^{5}$
}

\begin{abstract}
The survival of Acidovorax citrulli Aacl ${ }^{\text {Rif }}$ was accessed in infected melon tissues (fruits and leaves) incorporated to the soil at $0,5,10$ and $15 \mathrm{~cm}$ depth, in seven different types of soil, at temperatures $10,15,20,25,30$ and $35^{\circ} \mathrm{C}$ and moisture field capacity of 50 and $100 \%$ in the absence of the host plant. Aacl ${ }^{\text {Rif }}$ was detected in melon tissues at 0,5 and $10 \mathrm{~cm}$ until 21 days and at $15 \mathrm{~cm}$ until 14 days. The highest and lowest relative extinction rate of the population (RERP) for $A a c 1^{\mathrm{Rif}}$ occurred respectively in fruit tissues and leaf tissues at depths of 0 and $5 \mathrm{~cm}$. $A a c l^{\text {Rif }}$ survived in seven types of soil only for three days. The lowest RERP occurred at 10 or $15^{\circ} \mathrm{C}$ and the highest at 30 or $35^{\circ} \mathrm{C}$. Greater concentrations of $\mathrm{Na}^{+}$, silt, and greater populations of actinomycetes and Trichoderma were correlated with highest RERP of the $A a c l^{\text {Rif }}$ in the soil. There was significant difference between RERP at $100 \%$ and $50 \%$ of field capacity. The soil was not considered potential primary source of $A$. citrulli inoculum. Infected melon fruits and leaves in soil were considered as such sources, at least for 21 days.
\end{abstract}

Index terms: Cucumis melo, bacterial fruit blotch, populational density, ecology, management

\section{Sobrevivência de Acidovorax citrulli em tecidos infectados de melão e em diferentes condições edafoclimáticas}

Corresponding author: aldeoli@hotmail.com

Received: Janeiro 17, 2018. Accepted :May 17, 2018.

Copyright: All the contents of this journal, except where otherwise noted, is licensed under a Creative Commons Attribution License.

\begin{abstract}
Resumo - A sobrevivência de Acidovorax citrulli Aac $1^{\text {Rif }}$ foi estudada em tecidos infectados de frutos e folhas de melão incorporadas ao solo a $0 ; 5 ; 10$ e $15 \mathrm{~cm}$ de profundidade, em sete diferentes tipos de solo, às temperaturas de $10 ; 15 ; 20 ; 25 ; 30$ e $35^{\circ} \mathrm{C}$ e umidade na capacidade de campo de 50 e $100 \%$, na ausência da planta hospedeira. $A a c l^{\text {Rif }}$ foi detectado em frutos de melão e tecidos foliares a $0 ; 5$ e $10 \mathrm{~cm}$ até 21 dias, e a $15 \mathrm{~cm}$ até 14 dias. A taxa de extinção relativa mais alta e mais baixa da população (TERP) para $A a c l^{\text {Rif }}$ ocorreu, respectivamente, nos tecidos de frutos e nos tecidos foliares, às profundidades de 0 e $5 \mathrm{~cm}$. Para a maioria dos solos, a TERP mais baixa ocorreu a 10 ou $15^{\circ} \mathrm{C}$, e a mais alta, a 30 ou $35^{\circ} \mathrm{C}$. Maiores concentrações de $\mathrm{Na}^{+}$, silte e maiores populações de actinomicetos e Trichoderma foram correlacionadas com maior TERP de Aacl $1^{\text {Rif }}$ no solo. Houve diferença significativa entre a TERP em $100 \%$ e $50 \%$ da capacidade do campo. O solo não foi considerado fonte primária potencial de inóculo de $A$. citrulli. Os frutos e folhas de melão infectados no solo foram considerados como fontes de inóculo, pelo menos por 21 dias. Termos para indexação: Cucumis melo, mancha aquosa, densidade populacional, ecologia, manejo
\end{abstract}




\section{Introduction}

Bacterial fruit blotch (BFB) is one of the most destructive diseases in melon (Cucumis melo L.) and watermelon (Citrullus lanatus (Thunb.) Matsum. \& Nakai) on producing regions throughout the world (BURDMAN; WALCOTT, 2012). BFB is caused by Acidovorax citrulli (Schaad et al.) Schaad et al. (Schaad et al., 2008) that appears in the EPPO (European and Mediterranean Plant Protection Organization) Alert List (CABI, 2015). In Brazil, the most significant economic impact of BFB is on melon crops (CARVALHO et al., 2013) mainly cultivated and exported in Ceará and Rio Grande do Norte. In these states, BFB crop losses are estimated at $40-50 \%$, but could reach 100\% (EPPO, 2013).

Seeds represent the most important source of primary inoculum for BFB outbreaks. This confirms what has been observed in field, that expanded leaves and stems are the main inoculum sources for melon blossoms and fruit (ALVES et al., 2010). Volunteer cucurbit seedlings, noncucurbit and cucurbit weeds, and infected plant debris are also potential inoculum sources; however, these are not important in all environments (BURDMAN; WALCOTT, 2012). Developing better management practices depends on having knowledge of saprophytic dynamics of $A$. citrulli, but few studies were conducted on survival of the bacteria in crop residues and soil. A. citrulli survives in the soil for a few weeks during the summer in the absence of watermelon plants (ISAKEIT, 1999). However, Silva et al. (2006) detected the decline of $A$. citrulli populations over a 60-day period, from more than $10^{7}$ cells $\mathrm{mL}^{-1}$ to 10 cells and to 100 cells, in rhizosphere soil and melon roots, respectively. In crop residues, the bacterium has been recovered from fragments of watermelon rinds buried at 20 to $30 \mathrm{~cm}$ for 10 months (LATIN et al., 1995).

The bacterial survival in soil is influenced by abiotic factors such as temperature, moisture and $\mathrm{pH}$ (JANSE, 2005) and depends on their ability to resist a lack of nutrients and water, and exposure to heavy metals (GREY; STECK, 2001; HASHIMOTO et al., 2006). None study were found about the influence of chemical and physical characteristics of the soil on the survival of $A$. citrulli.

Seed disinfestation treatments, seed health testing and chemical control in the field are limited in their ability to reduce the yield losses associated with BFB. In addition, to date, there are no reliable sources of BFB resistance (BURDMAN; WALCOTT, 2012). A better comprehension of the ecology of $A$. citrulli will contribute toward the development of BFB new management strategies.

This study aimed to analyze the survival of the bacterium (i) in fruit and leaf tissues incorporated in the soil at different depths, and (ii) in different types of soil of the northeast region of Brazil in the absence of the host plant under the influence of different temperatures and moisture levels.

\section{Material and Methods}

\section{Bacterial strain}

The A. citrulli spontaneous rifampicin-resistant mutant $\left(A a c l^{\mathrm{Rif}}\right)$ used in this study was obtained from the Culture Collection Rosa Mariano of the Laboratory of Plant Bacteriology, Federal Rural University of Pernambuco, and was originally isolated from melon plant exhibiting typical BFB symptoms. The strain Aacl (syn. AAC201-21) belongs to the Group I of $A$. citrulli sensu Walcott et al., which includes strains isolated mainly from non-watermelon plants (WALCOTT et al., 2004).

In previous studies, A. citrulli Aacl ${ }^{\mathrm{Rif}}$ showed growth in liquid culture medium and pathogenicity similar to the rifampicin-sensitive parental strain (SILVA et al., 2006). In all survival studies, A. citrulli Aacl ${ }^{\mathrm{Rif}}$ was cultivated on nutrient yeast dextrose agar medium (PUSEY; WILSON, 1984) amended with rifampicin at 1 $\mathrm{mg} \mathrm{mL}^{-1}\left(\mathrm{NYDA}^{\text {Rif }}\right)$; suspensions of mutant were prepared in distilled water and the optical density was adjusted in a spectrophotometer model $500 \mathrm{M}$ (Analyser) to $\mathrm{A}_{560}$ $=0.25$, which corresponds to $3.4 \times 10^{7}$ colony forming units $(\mathrm{CFU}) \mathrm{mL}^{-1}$.

Survival of $A$. citrulli in infected melon tissues buried in the soil at different depths

To produce infected melon tissues, fruits and leaves of yellow hybrid AF4945 were inoculated with the A. citrulli Aac $1^{\text {Rif }}$ utilizing the sub-epidermal injection method (SOMODI et al., 1991) and atomization until runoff, respectively. Ten days after inoculation, symptomatic fruits and leaves were collected separately and fragmented into pieces of approximately $1 \mathrm{~cm}$. Ten grams of tissue were individually placed in plastic mesh bags with openings of $2 \times 2 \mathrm{~mm}$ and dimensions of $8 \times 5 \mathrm{~cm}$ and incorporated to the soil $\left[\mathrm{pH}\right.$ in water $=5.1 ; \mathrm{P}^{+}=6 \mathrm{mg}\left(\mathrm{dm}^{3}\right)^{-}$ ${ }^{1} ; \mathrm{Na}^{+}=0.31 \mathrm{mg}\left(\mathrm{dm}^{-3}\right)^{-1} ; \mathrm{K}^{+}=0.03 \mathrm{mg}\left(\mathrm{dm}^{-3}\right)^{-1} ; \mathrm{Ca}^{2+}+$ $\mathrm{Mg}^{2+}=1.45 \mathrm{mg}\left(\mathrm{dm}^{-3}\right)^{-1} ; \mathrm{Ca}^{2+}=0.9 \mathrm{mg}\left(\mathrm{dm}^{-3}\right)^{-1} ; \mathrm{Al}^{3+}=0.25$ $\mathrm{mg}\left(\mathrm{dm}^{-3}\right)^{-1}$; potential acidity $(\mathrm{H}+\mathrm{Al})=5.2 \mathrm{mg}\left(\mathrm{dm}^{-3}\right)^{-1}$; organic C. $=11.52 \mathrm{mg}\left(\mathrm{dm}^{-3}\right)^{-1}$; organic matter. $=19.86 \mathrm{mg}$ $\left.\left(\mathrm{dm}^{-3}\right)^{-1}\right]$. The bags were buried side by side at four depths [0 (surface), 5,10 and $15 \mathrm{~cm}$ ] in plastic columns of 20 $\mathrm{cm}$ height $\mathrm{x} 10 \mathrm{~cm}$ diameter, containing $2 \mathrm{~kg}$ of soil, and kept inside a greenhouse where the average air and soil temperature, and the relative humidity were monitored. The plastic columns were periodically wetted to maintain the soil moisture close to the field capacity $(90 \%)$.

The bags containing plant tissue were sampled at 7-day intervals until two successive samples failed in detected A. citrulli Aacl ${ }^{\text {Rif }}$. Five bags per depth and type of infected tissue were collected in each sample. Following manual sample homogenization, $1 \mathrm{~g}$ from each bag was macerated. This macerated tissue was added to $9 \mathrm{~mL}$ of sterilized distilled water (SDW) in tubes, and sonicated with an Ultra Sony ${ }^{\mathrm{TM}}$ 5B (Dentsply Neytech) for $5 \mathrm{~min}$ 
at $46 \mathrm{KHz}$. Serial dilutions were made up to $10^{-3}$, and 0.1 $\mathrm{mL}$ of each dilution was plated on NYDA ${ }^{\text {Rif }}$, with three replicates. The Petri dishes were incubated for $36 \mathrm{~h}$ at 30 ${ }^{\circ} \mathrm{C}$ in a Biochemical Oxygen Demand incubator (B.O.D. Mod. TE-391, Tecnal).

Evaluations were carried out by counting the number of typical colonies of the A. citrulli Aacl ${ }^{\text {Rif }}$, to determine the population in $\mathrm{CFU} \mathrm{g} \mathrm{g}^{-1}$ of soil. These data were used to calculate the relative extinction rate of the population (RERP), determined by the formula RERP = - $\left[\left(\log \mathrm{Y}_{\mathrm{f}}-\log \mathrm{Y}_{0}\right) /\left(\mathrm{T}_{\mathrm{f}}-\mathrm{T}_{0}\right)\right]$, where $\mathrm{Y}_{0}$ is the population at the first evaluation, $\mathrm{Y}_{\mathrm{f}}$ is the population at the last evaluation prior to reaching zero, $\mathrm{T}_{\mathrm{f}}$ is the time (in days) of the last evaluation prior to reaching zero and $\mathrm{T}_{0}$ is the time of the first evaluation (KOCKS, 1998).

The experimental design was completely randomized, with four treatments for leaves or fruit, representing the depths distribution $(0,5,10,15 \mathrm{~cm})$ of the bags in the soil with five replicates for each sampling, where each replicate constituted a plastic mesh bag containing infected tissue.

\section{Survival of $\boldsymbol{A}$. citrulli in different types of soil}

The survival of $A$. citrulli Aac $1^{\text {Rif }}$ was evaluated in seven types of soil collected, from a depth of 0-20 cm, in the states of Rio Grande do Norte and Ceará (Brazil) in melon fields with the occurrence of bacterial fruit blotch epidemics (Table 1). Soil samples were air dried over 15 days.

Each soil sample (200 g) was placed in a plastic box $\left(\right.$ Gerbox $\left.^{\circledR}-11 \mathrm{~cm} \times 11 \mathrm{~cm} \mathrm{x} 4 \mathrm{~cm}\right)$ and $50 \mathrm{~mL}$ of $A$. citrulli Aacl $^{\text {Rif }}$ suspension was added at a concentration

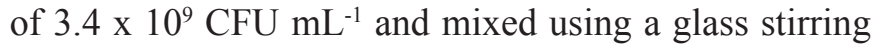
rod. The boxes were incubated in B.O.D. (Bio-Oxygen Demand) at $30{ }^{\circ} \mathrm{C}$. For the evaluation of the pathogen population counts, $1 \mathrm{~g}$ samples of soil were processed daily, based on the methodology described in the previous experiment. The experimental design was completely randomized, with seven treatments and four replicates, where one gerbox constituted a replicate.

The samples of the seven types of soil were analyzed for physical, chemical and microbiological characteristics. The physical and chemical analyses were performed immediately after soil sampling (EMBRAPA, 1997). These included granulometry, flocculation, residual moisture, available water, $\mathrm{pH}$ in water, available $\mathrm{P}(\mathrm{mg}$ $\left.\left(\mathrm{dm}^{3}\right)^{-1}\right), \mathrm{Na}^{+}, \mathrm{K}^{+}, \mathrm{Ca}^{2+}+\mathrm{Mg}^{2+}$, changeable $\mathrm{Ca}^{2+}$ and $\mathrm{Al}^{3+}$ $\left(\mathrm{cmol}\left(\mathrm{dm}^{3}\right)^{-1}\right)$, potential acidity $(\mathrm{H}+\mathrm{Al})$, organic $\mathrm{C}$ and organic matter $\left(\mathrm{g} \mathrm{kg}^{-1}\right)$.

In the microbiological analysis, ten sub-samples of $10 \mathrm{~g}$ each were mixed, and from this composite sample, $0.5 \mathrm{~g}$ was weighed out. To this aliquot, $4.5 \mathrm{~mL}$ of SDW was added, homogenized, and serial dilutions were performed until reaching $10^{-3}$ of the original. Next, $0.1 \mathrm{~mL}$ of each dilution was plated on different culture media with three replicates. Potato dextrose agar medium-PDA (TUITE, 1969) with the addition of 250 ppm of tetracycline was used to isolate fungi; NYDA for isolating bacteria; King's B medium-KB (KING et al., 1954) to isolate fluorescent Pseudomonas spp.; Starch casein agar modified medium-MSCA (VARGAS GIL et al., 2009) to isolate actinomycetes; and Malt extract agar medium-MEA (MARTIN, 1950) for the selective isolation of Trichoderma spp. In the Bacillus spp. isolation, the dilutions were heated in a water bath $\left(\operatorname{Evlab}^{\circledR}\right)$ at $80{ }^{\circ} \mathrm{C}$ for 20 minutes, with subsequent plating on PDA medium. For fungal isolation, plates were incubated at $25 \pm 2{ }^{\circ} \mathrm{C}$ under alternating light ( $12 \mathrm{~h}$ of 15 -watt light $/ 12 \mathrm{~h}$ dark) in B.O.D. All plates were incubated at $28 \pm 2{ }^{\circ} \mathrm{C}$. The bacterial growth was evaluated after 48 hours, while actinomycetes and fungi were evaluated after 5 days. Each population was determined from the mean of number of colonies on three plates and expressed in $\mathrm{CFU} \mathrm{g^{-1 }}$ of soil.

\section{Survival of $A$. citrulli in soils at different temperatures}

To evaluate the influence of temperature on survival of $A$. citrulli $A a c 1^{\text {Rif }}$ in seven different types of soil (Table 1), each soil sample (200 g) was placed in gerbox and $50 \mathrm{~mL}$ of bacterial suspension $\left(3.4 \times 10^{9}\right.$ CFU $\mathrm{mL}^{-1}$ ) was added and homogenized using a glass stirring rod. The gerbox were incubated in B.O.D. at constant temperatures of $10,15,20,25,30$ and $35^{\circ} \mathrm{C}$. The samples were processed daily as previously described. The experimental design was completely randomized with a factorial arrangement of $7 \times 6$ representing seven types of soil $\mathrm{x}$ six temperatures, with four replicates, where one gerbox constituted a replicate.

\section{Survival of $A$. citrulli in soil with different moisture levels}

To evaluate the influence of moisture on survival of $A$. citrulli Aacl ${ }^{\text {Rif }}$ in seven different types of soil (Table $1)$, each soil sample $(200 \mathrm{~g})$ was placed in gerbox and maintained at field capacity $(100 \%)$ and $50 \%$ of field capacity, determined by constant weight. Then $50 \mathrm{~mL}$ of bacterial suspension $\left(3.4 \times 10^{9} \mathrm{CFU} \mathrm{mL}^{-1}\right)$ was added and homogenized using a glass rod. The boxes were incubated in B.O.D. at $30^{\circ} \mathrm{C}$ and the samples processed daily, as previously described. The experimental design was completely randomized, with a factorial arrangement of $7 \times 2$ representing seven types of soil $x$ two levels of moisture, with four replicates, where one box constituted a replicate. 


\section{Statistical analysis}

All assays were replicated to determine the consistency of the results. Given that significant differences in the variances of the experimental replicates were not observed $(\mathrm{P}<0.05)$, the data were evaluated as replicates in time. The relative extinction rates obtained in the experiments were submitted to ANOVA and the Duncan's test or the Student's t-test $(\mathrm{P}<0.05)$ were used to separate the means. Standard deviations of the means were also calculated. To compare results of pathogen survival in the soil and all the soil characteristics, Pearson's correlation analysis was used. All the statistical analyses were performed using SAEG software (System for Statistical and Genetic Analysis, version 9.0, 2005, Universidade Federal de Viçosa, Brazil).

\section{Results}

Survival of $A$. citrulli in infected melon tissues buried in the soil at different depths

In both experiments the greenhouse conditions were similar: average air temperature $\left(30 \pm 2{ }^{\circ} \mathrm{C}\right)$, soil temperature $\left(28 \pm 2{ }^{\circ} \mathrm{C}\right)$ and the relative air moisture $(90$ $\pm 3 \%)$.

A. citrulli Aacl ${ }^{\mathrm{Rif}}$ survived in the tissues of melon for 21 days at depths of 0 (surface), 5 and $10 \mathrm{~cm}$ and for 14 days at a depth of $15 \mathrm{~cm}$ (Figure 1a and b). Larger bacterial populations were found in melon fruit tissues at 7 and 14 days in depths of 0 and $5 \mathrm{~cm}$ than at depths of 10 and $15 \mathrm{~cm}$. At 21 days, populations in this tissue at 0,5 and $10 \mathrm{~cm}$ were similar, with values of $3.86 \times 10^{3}$, $3.66 \times 10^{3}$ and $3.3 \times 10^{3} \mathrm{CFU} \mathrm{g}^{-1}$ of tissue, respectively, whereas A. citrulli Aacl ${ }^{\text {Rif }}$ was no longer detected at 15 $\mathrm{cm}$ (Figure 1a).

In leaf tissues at 7 and 14 days, the populations were similar at all depths, whereas the A. citrulli Aac ${ }^{\text {Rif }}$ population at $10 \mathrm{~cm}$ declined considerably at 21 days (3.38 $\times 10^{3} \mathrm{CFU} \mathrm{g}^{-1}$ of tissue) in relation to the 0 and 5 cm depths $\left(4.27 \times 10^{4}\right.$ and $4.16 \times 10^{4} \mathrm{CFU} \mathrm{g} \mathrm{g}^{-1}$ of tissue $)$ and was not detected at $15 \mathrm{~cm}$ (Figure $1 \mathrm{~b}$ ). On the $28^{\text {th }}$ day, no population was detected at any depth in the tissues (Figure 1a and $\mathrm{b}$ ).

The highest and lowest RERP for A. citrulli $\mathrm{Aacl}^{\mathrm{Rif}}$ occurred respectively in fruit [0.15 and $0.14 \log$ (CFU) day $^{-1}$ ] and leaf tissues [0.03 and $0.04 \log (\mathrm{CFU})$ day $^{-1}$ ] at depths of 0 and $5 \mathrm{~cm}$. The RERP in the two types of tissue were very similar at 10 and $15 \mathrm{~cm}$ (Figure 2). It is important to point out that the highest RERP for the leaf tissues $\left[0.08 \log (\mathrm{CFU})\right.$ day $\left.^{-1}\right]$ were observed at $10 \mathrm{~cm}$ (Figure 2).

\section{Survival of $A$. citrulli in different types of soil}

Regardless of the type of soil, A. citrulli Aacl Rif survived only three days in the seven melon crop soils. However, RERP ranged from 0.51 to $0.91 \log (\mathrm{CFU})$ day $^{-}$
${ }^{1}$, with the formation of three groups of soil. The highest RERP occurred in Soil C and the lowest occurred in Soils E and G (Table 1).

In the analysis of possible indicators that influenced A. citrulli Aac $\mathrm{I}^{\mathrm{Rif}}$ survival in the different soils, significant correlations $(\mathrm{P}=0.05)$ were found between RERP and the chemical, physical and microbiological characteristics of the soil. RERP were positively correlated with the concentration of $\mathrm{Na}^{+}(\mathrm{r}=0.86)$ and $\operatorname{silt}(\mathrm{r}=0.86)$ as well as the population of actinomycetes $(\mathrm{r}=0.93)$ and Trichoderma $(\mathrm{r}=0.82)$ in the soils. These factors extinguished the bacterial population in the soil more quickly (higher RERP), which is verified by comparing Soils C, E and G (Table 1). The efficiency of these factors in the extinction of the bacterial population were also either positively or negatively correlated with other characteristics of the soil: $\mathrm{Na}^{+}$with silt $(\mathrm{r}=0.82)$, sand with silt $(\mathrm{r}=-0.82)$, clay with silt $(\mathrm{r}=0.71)$, silt with actinomycetes $(\mathrm{r}=$ $0.83)$, Pseudomonas with actinomycetes $(\mathrm{r}=-0.79)$ and actinomycetes with Trichoderma $(\mathrm{r}=0.082)$.

\section{Survival of $A$. citrulli in soils at different temperatures}

Temperature did not affect the survival time of $A$. citrulli Aac $1^{\text {Rif }}$ in the different soils and, as confirmed in the previous experiments, the time needed for the extinction of the bacterial population were three days. However, temperature affected the RERP of A. citrulli Aac1 ${ }^{\text {Rif }}$, indicating the best and worst temperature ranges for the survival of this pathogen (Figure 3).

For most of the soils, the lowest RERP were reached at 10 or $15^{\circ} \mathrm{C}$ and the highest were reached at 30 or $35^{\circ} \mathrm{C}$. The bacterium behaved similarly to that of the previous experiments, exhibiting higher RERP in Soil C [mean value of $1.11 \log (\mathrm{CFU})$ day $\left.^{-1}\right]$ and the lowest in Soils $\mathrm{E}$ [mean value of $0.89 \log (\mathrm{CFU})$ day $^{-1}$ ] and $\mathrm{G}$ [mean value of $0.78 \log (\mathrm{CFU})$ day $^{-1}$. In Soil C, the RERP increased with the temperature, with greater survival of $A$. citrulli $A a c 1^{\text {Rif }}$ at $10^{\circ} \mathrm{C}$ and lowest survival at $30^{\circ} \mathrm{C}$ (Figure 3).

\section{Survival of $A$. citrulli in soil with different moisture levels}

In the analysis of variance, no significant interaction $(\mathrm{P}=0.05)$ were found between the soils and moisture. Regardless of the moisture level, there were a significant difference in the RERP of $A$. citrulli Aac ${ }^{\text {Rif }}$ in the seven soils (data not presented), confirming previously obtained results.

Significant difference ( $\mathrm{P}=0.05$, Student's t-test $)$ between RERP at moisture levels of 100\% [0.67 log (CFU) day $\left.^{-1}\right]$ and $50 \%$ [0.50 log (CFU) day $\left.{ }^{-1}\right]$ of field capacity, with a more rapid extinction of the bacterial population when the soil was at $100 \%$ moisture, regardless of the moisture level, A. citrulli Aacl ${ }^{\text {Rif }}$ also only survived in the soils for three days. 


\section{Discussion}

In the present study, it was demonstrated that fruit and leaf tissues can be potential inoculum sources of $A$. citrulli for new crops, depending on the depth of incorporation into the soil, surviving the bacteria for up to 21 days when tissues are at a maximum depth of $10 \mathrm{~cm}$.

In fruit tissues, the largest bacterial populations were detected at 0 and $5 \mathrm{~cm}$ and the highest RERP of A. citrulli Aacl ${ }^{\text {Rif }}$ were also observed at these depths, logically because the final populations at 0,5 and $10 \mathrm{~cm}$ were similar on $21^{\text {th }}$ day. This means that probably the population decline at 0 and $5 \mathrm{~cm}$ was more pronounced. There is a small degree of microorganism activity at 0 and $5 \mathrm{~cm}$ (MOREIRA; SIQUEIRA, 2006), which enabled greater colonization of $A$. citrulli Aacl ${ }^{\mathrm{Rif}}$ at these depths than at 10 and $15 \mathrm{~cm}$ through to $14^{\text {th }}$ day. However, with the gradual decomposition of the fruit over time, all that were left were the dehydrated rind, which is inhospitable to the bacterial survival, especially on the surface of the soil. At other depths, the maintenance of the moisture content may have favored the saprophytic activity of the inhabitants in the soil throughout the experimentation period. Thus, there was an accentuated decrease in population on $21^{\text {th }}$ day at all depths and total extinction by $28^{\text {th }}$ day. In leaf tissues, the lesser influence of the depth of incorporation on the populations and RERP of $A$. citrulli Aacl ${ }^{\text {Rif }}$, especially on days 7 and 14, may be attributed to the greater uniformity of the leaf tissue (midrib and main veins) in comparison to fruit tissue (rind and pulp), as the fruit pulp is easily degradable due to the greater water content. The short survival time observed in the present study of $A$. citrulli $A a c 1^{\text {Rif }}$ in infected tissues may vary depending on the microbiota, type of soil, cucurbitaceae host and climatic conditions. Latin et al. (1995) found greater survival of A. citrulli in fragments of watermelon rinds buried for ten months at a depth of 20 to $30 \mathrm{~cm}$.

The highest RERP occurred when the leaf tissue was incorporated to $10 \mathrm{~cm}$ of soil. This effect was likely due to the greater contact of the infected tissues with the soil environment, which exhibits fewer abrupt environmental fluctuations beginning at a depth of $10 \mathrm{~cm}$, thereby providing greater equilibrium in the population and microbial activity, resulting in a more accelerated decomposition of the crop residues and lower survival of the pathogen. Furthermore, incorporation at $10 \mathrm{~cm}$ or deeper favors a quicker loss of cell viability by submitting the tissue to the greater moisture of the soil, which rises with the increase in depth. The lower RERP of $A$. citrulli $A a c 1^{\text {Rif }}$ in the leaf tissues deposited at 0 and $5 \mathrm{~cm}$ may result from the small degree of degrading associated with microorganism activity, which gradually increases by depths of $10 \mathrm{~cm}$ (MOREIRA; SIQUEIRA, 2006). 
A number of reports on bacteria that cause leaf damage confirm greater survival on the surface of the soil. The leaf pathogens of the cruciferous Xanthomonas campestris pv. armoraciae (McCulloch) Dye and Pseudomonas syringae pv. maculicola (McCulloch) Young et al. survived in crop residues of turnips (Brassica rapa L.) and cabbage (B. oleracea L.) buried for 60 days, even when the residues were decomposed, whereas residues on the surface were recovered through to 150 days (ZHAO et al., 2002). Rifampicin-resistant mutant of $X$. axonopodis pv. allii Roumagnac et al. (strain O177) was recovered from infected onion leaves (Allium cepa L.) about 9 months after they were placed on the soil surface or buried to a depth of $25 \mathrm{~cm}$ (GENT et al., 2005). $X$. campestris pv. citri (Hasse) Dye was detected after 120 days in lesions of grapevine leaves placed on the soil surface but only up to 85 days when leaves were buried 10 $\mathrm{cm}$ deep, in the Argentina but the decline rate in bacterial populations was significantly greater in buried leaves than in surface leaves (GRAHAN et al., 1987).

The incorporation depth of the infected melon fruit and leaves directly influenced the populations and RERP of A. citrulli Aacl ${ }^{\text {Rif }}$, reducing the capacity of infested residuals to support the pathogen survival. Despite the fact that higher RERP for fruit and leaves occurred at 0-5 and $10 \mathrm{~cm}$, respectively, it is more important to consider that bacterial populations were no longer detected after 21 days only at the $15-\mathrm{cm}$ depth.

While A. citrulli Aacl ${ }^{\text {Rif }}$ survived in the infected tissues for 21 days in the absence of a host plant, regardless of the type, temperature and moisture of the soil, the pathogen was only detected for three days, indicating a limited survival capacity in the soil under tropical conditions. Silva et al. (2006) found that A. citrulli survived better on melon plant leaves than the roots and rhizosphere under greenhouse and field conditions. These results suggest that $A$. citrulli is probably a leaf pathogen, belonging to Group A of the Buddenhagen classification (BUDDENHAGEN, 1965), the populations of which are nearly exclusively developed on the host, undergoing rapid decline in the soil, which does not contribute toward the propagation of the disease from one season to the next.

Based on the RERP of A. citrulli Aacl ${ }^{\text {Rif }}$, the seven soils studied were separated into three groups. However, it were not pertinent to classify them as suppressive or conducive, as the bacterium only survived for three days, regardless of the soil type. Nonetheless, some chemical, physical and biological characteristics of the soils were correlated to RERP and may have been the causes of the more rapid decline in the population of the pathogen in Soil C. These characteristics were high concentrations of sodium $\left(\mathrm{Na}^{+}\right)$and silt as well as large populations of actinomycetes and Trichoderma, which merit mention. The planktonic survival in the soil is short for many bacterial pathogens. There is a rapid decline in population, most probably because they compete poorly with the soil microflora and due to lack of appropriate nutrients (JANSE, 2005).

Bacterial cells maintain osmotic balance through the constant pumping of protons and other ions $\left(\mathrm{Na}^{+}\right)$to the exterior of the cell through transport proteins located in the cytoplasmic membrane (TORTORA et al., 2015). Thus, a larger amount of $\mathrm{Na}^{+}$in the soil may lead to an imbalance in the cell metabolism.

Soils with high silt content hinder the deep infiltration of water and consequently affect the amount of water available to microorganisms. In the present study, the presence of silt was positively correlated to the amount to clay, which has a high ability for retaining water and promoting soil expansion. This characteristic decreases the effect of irregular rains and increases microbial life (DAVET, 2004). It was also determined that Soil C had a larger amount of clay (47.20\%) than Soils E and G.

The high correlation between RERP and microbial populations in the soil were expected. Bacteria from the group of actinomycetes and diverse species of Trichoderma are abundant in tropical soils. Both are considered saprophytes and efficient in acting as antagonists of a number of phytopathogens of economic importance through antibiosis, parasitism, production of other toxic substances or volatile inhibitors and enzymatic activity inhibitors, competition for nutrients and / or substrate (Di FRANCESCO et al., 2015; HARMAN, 2011; VINALE et al., 2008). However, the microbial balance and efficiency of an antagonist are dependent on the physiochemical characteristics of the soil and it is difficult to separate the factors involved in suppression (WELLER et al., 2002), which were evident in the present study through the significant correlations between the concentration of silt and actinomycetes $(\mathrm{r}=0.83)$, Pseudomonas and actinomycetes $(\mathrm{r}=-0.79)$ and actinomycetes and Trichoderma $(\mathrm{r}=0.082)$. As A. citrulli Aacl ${ }^{\mathrm{Rif}} \mathrm{did}$ not survive in the melon crop soil in the absence of the host plant for more than three days, the soil is not a potential source of primary inoculum for infections in the shoots of the plants. The majority of pathogenic bacteria that cause non-systemic diseases in the phyloplane are believed to encounter difficulty surviving in the soil without the host plant, as the microbial flora in the soil, as a rule, exercises considerable antagonism on these bacteria (JANSE, 2005).

Soil is an irregular, diverse and structured environment where bacteria could face stresses caused by restrictions in nutrient availability or fluctuations in time of physical and chemical factors (ELSAS et al., 2000). The temperature range around 30 to $35^{\circ} \mathrm{C}$ is considered optimum for the development of bacterial fruit blotch in melons (SILVEIRA et al. 2004) and the growth of $A$. citrulli on a culture medium. However, a higher RERP of the bacterium were generally determined at temperatures between 30 and $35^{\circ} \mathrm{C}$ as well as a lower temperature 
of $10{ }^{\circ} \mathrm{C}$. Mild temperatures reduce microbial activity, whereas high temperatures do the opposite (BAIRD et al., 1999). Thus, both the pathogen and the antagonists in the soil would have greater activity at 30 to $35^{\circ} \mathrm{C}$, but, as the latter are more adapted to this habitat, they may have been favored in detriment to the survival of $A$. citrulli. This would probably not occur in melon fruit or a culture medium in which the pathogen has all the most favorable conditions for the infection of tissue and cell growth.

The lower survival of $A a c{ }^{\text {Rif }}$ in the soil with $100 \%$ field capacity may be attributed to the lesser aeration of the soil. Aerobic microorganisms require $\mathrm{O}_{2}$ as a terminal receptor of electrons in the metabolism (TORTORA et al., 2015 ) and, in inundated soils, there is an accumulation of

$\mathbf{A}$

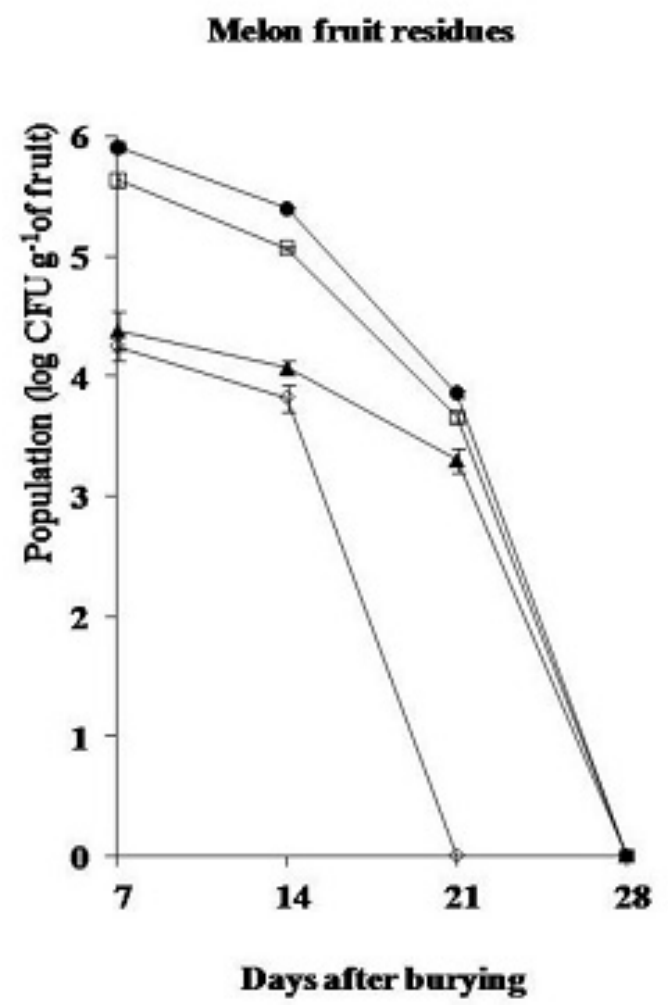

products from fermentative processes, such as short-chain organic compounds and reduced organic compounds that can accumulate in toxic concentrations, causing harm to microorganisms (MOREIRA; SIQUEIRA, 2006). Once again, the soil that exhibited the highest RERP was Soil C, which contained high silt and clay content (Table 1) and, consequently, a greater water retention capacity, as mentioned earlier.

In conclusion, the soil should not be considered a source of primary inoculum of $A$. citrulli, as this pathogen only survived for three days in the absence of the host plant. It is recommended that the management of bacterial fruit blotch include the incorporation of infected melon leaves and fruits tissues for tilling and maintenance of a minimum interval of 28 days between crops.

$\mathbf{B}$

Melon leaf residnes

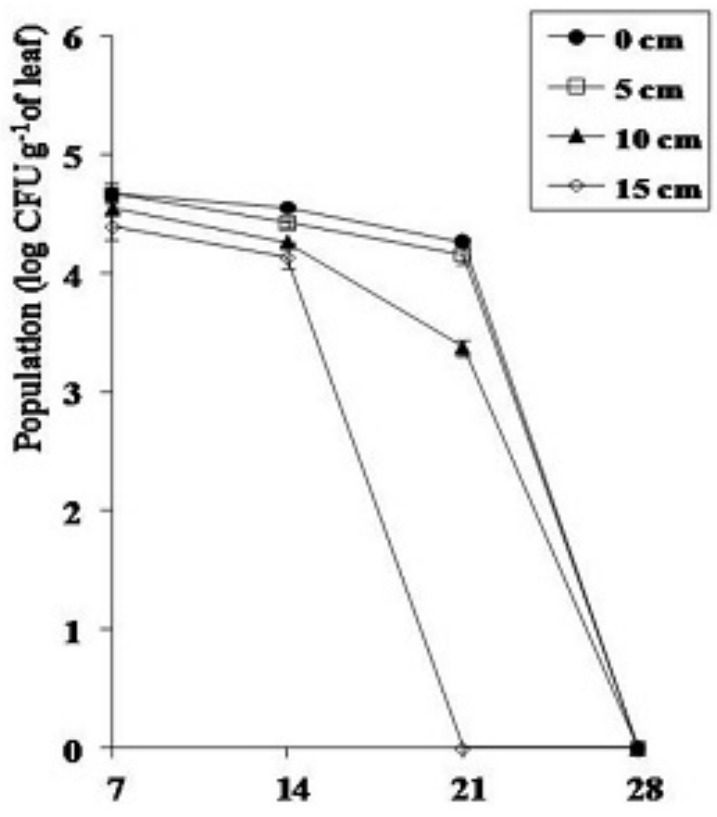

Days after burying

Figure 1 - Survival of A. citrulli Aac $1^{\text {Rif }}$ in infected melon fruits (A) and leaves (B) incorporated to the soil at different depths, evaluated by the bacterial population $\left(\log \mathrm{CFU} \mathrm{g}{ }^{-1}\right)$. Vertical bars represent the standard deviation of the mean. 
$\mathbf{A}$

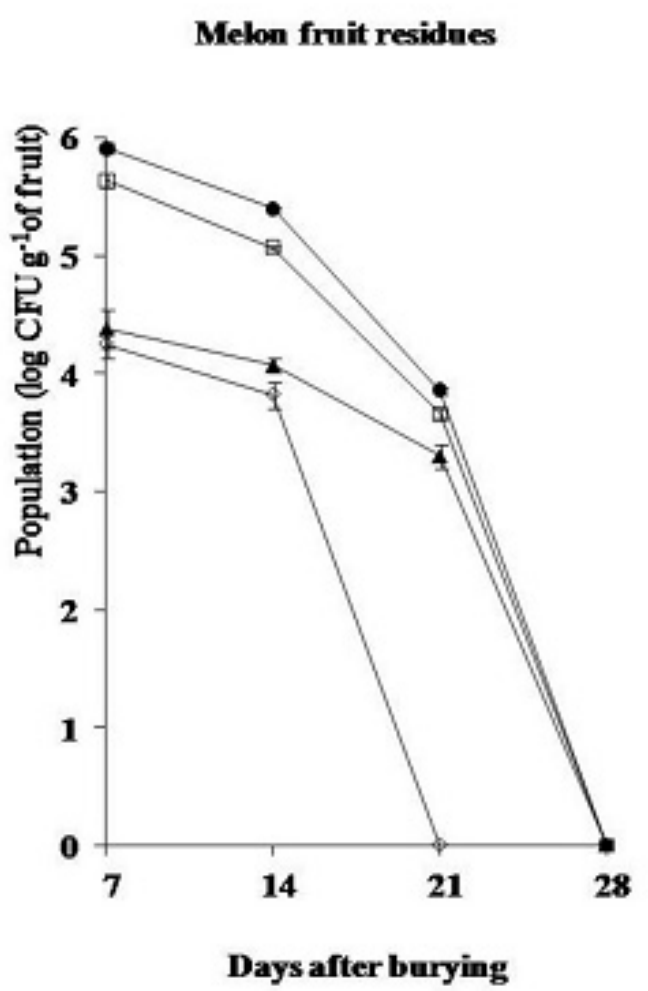

B

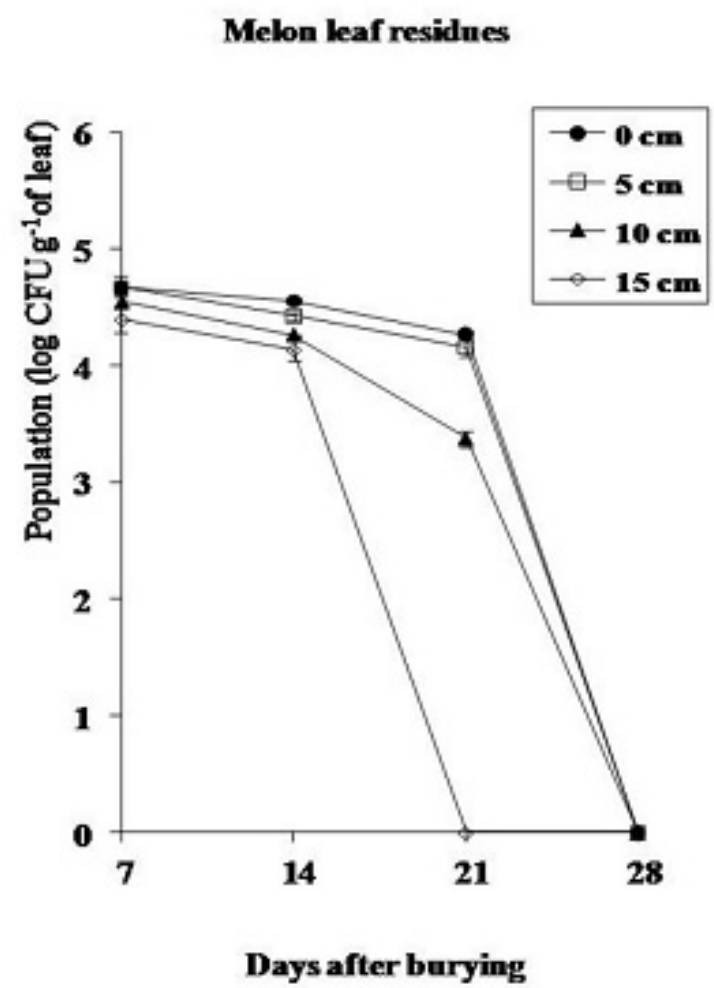

Figure 2 - Survival of A. citrulli Aacl ${ }^{\text {Rif }}$ in infected melon fruits and leaves incorporated to the soil at different depths, evaluated by the relative extinction rate of the bacterial population (RERP). Vertical bars represent the standard deviation of the mean.

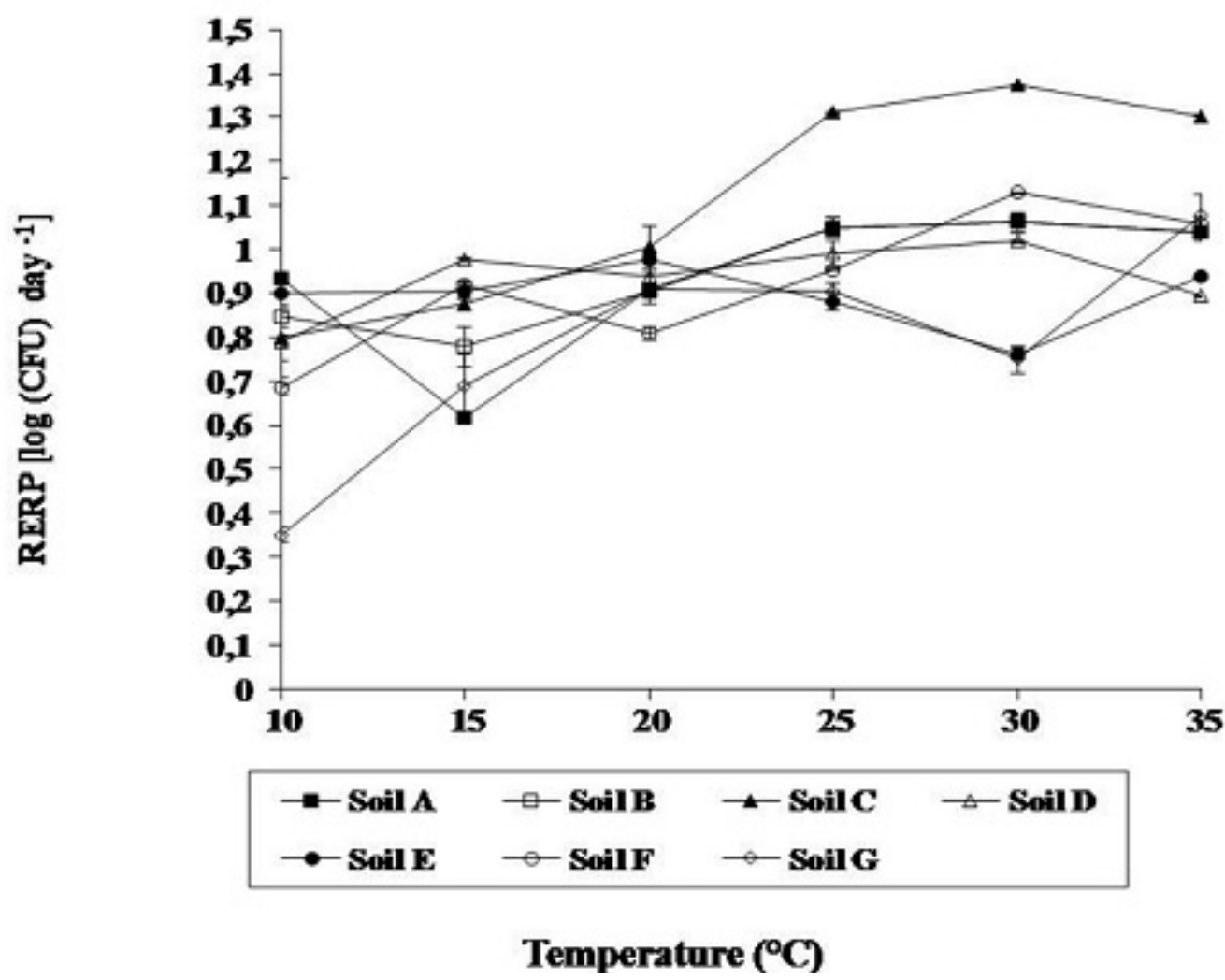

Figure 3 - Survival of $A$. citrulli Aac $1^{\text {Rif }}$ in seven melon crop soils from northeastern Brazil submitted to different temperatures, evaluated by the relative extinction rate of the bacterial population (RERP). Vertical bars represent the standard deviation of the mean. 


\section{Acknowledgments}

We thank the National Council for Scientific and Technological Development (CNPq) for a scholarship to A. O. Alves and for the research fellowships awarded to R. L. R. Mariano and E. B. Souza (Proc. 302078/2008-8)

\section{References}

ALVES, A.O.; XAVIER, A.S.; VIANA, I.O.; MARIANO, R.L.R.; SILVEIRA, E.B. Colonization dynamics of Acidovorax citrulli in melon. Tropical Plant Pathology, Brasília, DF, v.35, n.6, p.368-372, 2010.

BAIRD, R.E.; PHILLIPS, D.V.; MULLINIX, B.G.; ALT, P.J. Relative longevity of Leptosphaeria maculans and associated mycobiota on canola debris. Phytoprotection, Québec, v.80, n.1, p.1-11, 1999.

BUDDENHAGEN, I.W. The relation of plant- pathogenic bacteria to the soil. In: BAKER, K.F.; SNYDER, W.C. (Ed.). Ecology of soil-borne plant pathogens. Berkeley: University of California Press, 1965. p.269-284.

BURDMAN, S.; WALCOTT, R. Acidovorax citrulli: generating basic and applied knowledge to tackle a global threat to the cucurbit industry. Molecular Plant Pathology, Oxford, v.13, n.8, p.805-815, 2012.

CABI - Centre for Agriculture and Biosciences International. Acidovorax citrulli (fruit blotch. 2015. Disponível em: $<$ http://www.cabi.org/isc/datasheet/2676\#tab1 nav $>$. Acesso em: oct. 2016.

CARVALHO, F. C. Q.; SANTOS, L. A.; DIAS, R. C. S.; MARIANO, R. L. R.; SOUZA, E. B. Selection of watermelon genotypes for resistance to bacterial fruit blotch. Euphytica, Wageningen, v.190, n.2, p.169-180, 2013.

DAVET, P. (Ed.). Microbial ecology of the soil and plant growth. Paris: Science Publishers, 2004. 408p.

Di FRANCESCO, A.; UGOLINI, L.; LAZZERI, L.; MARI, M. Production of volatile organic compounds by Aureobasidium pullulans as a potential mechanism of action against postharvest fruit pathogens. Biological Control, Orlando, v.81, n.1, p.8-14, 2015.

ELSAS, J.D. van; KASTELEIN, P.; BEKKUM, P. van; WOLF, J.M. van der; VRIES, P.M. de; OVERBEEK, L.S. van. Survival of Ralstonia solanacearum biovar 2 , the causative agent of potato brown rot, in field and microcosm soils in temperate climates. Phytopathology, Saint Paul, v. 90, n.12, p.1358-1366, 2000.
EMBRAPA. Manual de métodos de análises de solo. Rio de Janeiro: Embrapa-CNPS, 1997. 212p.

EPPO - European and Mediterranean Plant Protection Organization. Acidovorax citrulli: bacterial fruit blotch of cucurbits. 2013. Disponível em: $<$ http://www.eppo.int/ QUARANTINE/Alert_List/bacteria/Acidovorax citrulli. $\underline{\mathrm{htm}>}$. Acesso em: dez. 2017.

GENT, D.H.; LANG, J.M.; BARTOLO, M.E.; SCHWARTZ, H.R. Inoculum sources and survival of Xanthomonas axonopodis pv. allii in Colorado. Plant Disease, Saint Paul, v.89, n.5, p.507-514, 2005.

GRAHAM, J.H.; MCGUIRE, R.G.; MILLER, J.W. Survival of Xanthomonas campestris pv. citri in citrus plant debris and soil in Florida and Argentina. Plant Disease, Saint Paul, v.71, n.12, p.1094-1098, 1987.

GREY, B.E.; STECK, T.R. The viable but nonculturable state of Ralstonia solanacearum may be involved in longterm survival and plant infection. Applied and Environmental Microbiology, Washington, v.67, n.9, p.3866-3872, 2001.

HARMAN, G E. Trichoderma - not just for biocontrol anymore. Phytoparasitica, Bet Dagan, v.39, n.2, p.103108, 2011.

HASHIMOTO, T.; WHANG, K.S.; NAGAOKA, K.A quantitative evaluation and phylogenetic characterization of oligotrophic denitrifying bacteria harbored in subsurface upland soil using improved culturability. Biology and Fertility of Soils, Berlin, v.42, n.3, p.179-185, 2006.

ISAKEIT, T. Bacterial fruit blotch in watermelon. Texas: The Agricultural Extension Service, 1999. (Publication, L-5222).

JANSE, J. D. (Ed.). Phytobacteriology: principles and practice. Cambridge: CABI Publishing, 2005. 368p.

KING, E.O.; WARD, M.K.; RANEY, D.E. Two simple media for the demonstration of pyocyanin and fluorescin. The Journal of Laboratory and Clinical Medicine, Saint Louis, v.44, n.2, p.301-307, 1954.

KOCKS, C.G. Survival and extinction of Xanthomonas campestris pv. campestris in soil. European Journal of Plant Pathology, Dordrecht, v.104, n.9, p.911-923, 1998.

LATIN, R.X.; TIKHONOVA, I.; RANE, K. Factors affecting the survival and spread of Acidovorax avenae subsp. citrulli in watermelon transplant production facilities. Phytopathology, Saint Paul, v.85, n.11, p.4131417, 1995. 
MARTIN, J. P. Use of acid, rose bengal, and streptomycin in the plate method for estimating soil fungi. Soil Science, Philadelphia, v.69, n.3, p.215-232, 1950.

MOREIRA, F.M.S.; SIQUEIRA, J.O. (Ed.). Microbiologia e bioquímica do solo. Lavras: Editora da UFLA, 2006. $729 \mathrm{p}$.

PUSEY, P.L.; WILSON, C.L. Postharvest biological control of stone fruit brown rot by Bacillus subtilis. Plant Disease, Saint Paul, v.68, n.9, p.753-756, 1984.

SCHAAD, N. W.; POSTNIKOVA, E.; SECHLER, A.; CLAFLIN, L. E.; VIDAVER, A. K.; JONES, J. B.; AGARKOVA, I.; IGNATOV, A.; DICKSTEIN, E.; RAMUNDO, B. A. Reclassification of subspecies of Acidovorax avenae as A. Avenae (Manns 1905) emend., A. cattleyae (Pavarino, 1911) comb. nov., A. citrulli Schaad et al., 1978) comb. nov., and proposal of $A$. oryzae sp. nov. Systematic Applied Microbiology, Stuttgart, v.31, n.6-8, p.434-446, 2008.

SILVA, V.A.V.; SILVEIRA, E.B.; MARIANO, R.L.R. Sobrevivência de Acidovorax avenae subsp. citrulli em meloeiro. Fitopatologia Brasileira, Brasília, DF, v.31, n.4, p.381-386, 2006.

SILVEIRA, E.B.; MARIANO, R.L.R.; MICHEREFF, S.J.; OLIVEIRA, S.M.A. Influência da temperatura, umidade, concentração de inóculo de Acidovorax avenae subsp. citrulli e idade do fruto no desenvolvimento da manchaaquosa em melão. Fitopatologia Brasileira, Brasília, DF, v.29, n.1, p.34-38, 2004.

SOMODI, G.C.; JONES, J.B.; HOPKINS, D.L.; STALL, R.E.; KUCHAREK, T.A.; HODGE, N.C.; WATTERSON, J.C. Occurrence of a bacterial watermelon fruit blotch in Florida. Plant Disease, Saint Paul, v.75, n.10, p.10531056. 1991.
TORTORA, G. J.; FUNKE, B. R.; CASE, C. L. Microbiology: an introduction. $12^{\text {th }}$ ed. New York: Pearson, 2015. 960p.

TUITE, J. Plant pathological methods fungi and bacteria. Minneapolis: Burgess Publishing Company, 1969. 239p.

VARGAS-GIL, S.; PASTOR, S.; MARCH, G. J. Quantitative isolation of biocontrol agents Trichoderma spp., Gliocladium spp. and actinomycetes from soil with culture media. Microbiological Research, Jena, v.164, n.2, p.196-205, 2009. (1) (mudar na p.6 linha 3 de (VARGAS GIL et al., 2008) para (VARGAS GIL et al., 2009)

VINALE, F.; SIVASITHAMPARAM, K.; GHISALBERTI, E. L.; MARRA, R.; WOO, S. L.; LORITO, M. Trichoderma-plant-pathogen interactions. Soil Biology and Biochemistry, Elmsford, v.40, n.1, p.1-10, 2008.

WALCOTT, R. R.; FESSEHAIE, A.; CASTRO, A. C. Differences in pathogenicity between two genetically distinct groups of Acidovorax avenae subsp. citrulli on cucurbit hozsta. Journal of Phytopathology, Berlin, v.152, p.277-285, 2004.

WELLER, D. M.; RAAIJMAKERS, J. M.; GARDENER, B. B. M.; THOMASHOW, L. S. Microbial populations responsible for specific soil suppressiveness to plant pathogens. Annual Review of Phytopathology, Palo Alto, v.40, n.1, p.309-348, 2002.

ZHAO, Y.; DAMICONE, J. P.; BENDER, C. L. Detection, survival, and sources of inoculum for bacterial diseases of leafy crucifers in Oklahoma. Plant Disease, Saint Paul, v.86, n.8, p.883-888, 2002. 